\title{
AGRICULTURAL USE OF TREATED SEWAGE EFFLUENTS: AGRONOMIC AND ENVIRONMENTAL IMPLICATIONS AND PERSPECTIVES FOR BRAZIL
}

\author{
Adriel Ferreira da Fonseca ${ }^{1,2 *}$; Uwe Herpin ${ }^{2}$; Alessandra Monteiro de Paula ${ }^{3}$; Reynaldo Luiz \\ Victória $^{1,2}$; Adolpho José Melfi' ${ }^{2,3}$ \\ ${ }^{1}$ USP/CENA - Lab. de Ecologia Isotópica, 13400-970 - Piracicaba, SP - Brasil. \\ ${ }^{2}$ USP/Nupegel, 13418-900 - Piracicaba, SP - Brasil. \\ ${ }^{3}$ USP/ESALQ, Depto. de Ciência do Solo, C.P 09 - 13418-900 - Piracicaba, SP - Brasil. \\ *Corresponding author <adrielff@gmail.com>
}

\begin{abstract}
In many studies worldwide the use of treated sewage effluents (TSE) as water and nutrient sources in agricultural irrigation have been introduced as a viable alternative for wastewater destination in the environment. Considering agronomic and environmental aspects the objectives of this review were: (i) to present an overview of TSE irrigation on different agro-systems (annual crops, orchards, forests and forages); and (ii) to show the principal changes on chemical, physical and microbiological soil characteristics after TSE application. Various studies have revealed that the nutrient supply only by TSE irrigation was not sufficient to meet plant nutrient requirements resulting in yield decreases. The problem could be solved by an adapted effluent/fertilizer management. Moreover, TSE could generally substitute efficiently freshwater for irrigation. Regarding soil quality conditions, TSE irrigation affected mainly: (i) total soil carbon and nitrogen, and mineral nitrogen in soil solution; (ii) microbial activity, composition of microbial communities and their function; (iii) exchangeable calcium and magnesium; (iv) salinity, sodicity, clay dispersion and hydraulic conductivity. Other soil parameters considered in this review (e.g. heavy metals) did not present significant changes over short and medium terms. Due to the often observed accumulation of sodium and nitrogen losses (leaching, volatilization and denitrification) after TSE irrigation, the monitoring of these components is of crucial importance for a sustainable use. Finally, further studies on the technical-economical-environmental viability of TSE irrigation are required to establish reliable recommendations for TSE use particularly in Brazilian agro-systems.
\end{abstract}

Key words: wastewater, water reuse, nutrient source, agriculture, environmental impact

\section{USO AGRÍCOLA DOS EFLUENTES DE TRATAMENTO DE ESGOTO: IMPLICAÇÕES AGRONÔMICO-AMBIENTAIS E PERSPECTIVAS PARA O BRASIL}

\begin{abstract}
RESUMO: O uso dos efluentes de tratamento de esgoto (ETEs) como fonte d'água e nutrientes na agricultura (via irrigação) tem sido, em diversos locais, uma alternativa viável para a disposição das águas residuárias no ambiente. Os objetivos dessa revisão foram: (i) enfocar aspectos agronômicos e ambientais concernentes ao uso de ETEs em diferentes agrossistemas (culturas anuais, fruticultura, florestas e forragens); (ii) enfatizar as principais mudanças nas características químicas, físicas e microbiológicas dos solos irrigados com ETEs. Foram observados que, em diversos trabalhos, a irrigação com ETEs não foi suficiente para atender a demanda nutricional das plantas, resultando em diminuição no rendimento. Esse problema poderia ser resolvido mediante adequação do manejo da fertilização e irrigação. Além disso, os ETEs poderiam substituir eficientemente a água doce normalmente empregada na irrigação. Quanto a qualidade de solo, a irrigação com ETEs tem alterado principalmente os parâmetros: (i) carbono total e nitrogênio total no solo e nitrogênio mineral na solução no solo; (ii) atividade, composição e função da comunidade microbiana; (iii) cálcio e magnésio trocáveis; (iv) salinidade, sodicidade, dispersão de argilas e condutividade hidráulica. Outros parâmetros de qualidade de solo (por exemplo, metais pesados) não apresentaram mudanças significativas em curto e médio prazo. O monitoramento da acumulação de sódio e das perdas de nitrogênio (lixiviação, volatilização e denitrificação) é crucial para o uso sustentável dos ETEs na irrigação. Finalmente, mais estudos são necessários para mostrar a viabilidade técnico-econômico-ambiental, objetivando-se a recomendação segura dos ETEs na irrigação dos agrossistemas brasileiros.

Palavras-chave: água residuária, reuso de água, fonte de nutrientes, agricultura, impacto ambiental
\end{abstract}

Sci. Agric. (Piracicaba, Braz.), v.64, n.2, p.194-209, March/April 2007 


\section{INTRODUCTION}

The use of treated sewage effluents (TSE) for agricultural irrigation is an old and popular practice in agriculture (Feigin et al., 1991). However, in Brazil this method is still recent (Fonseca et al., 2005a). Irrigation with TSE has been used for three purposes: (i) complementary treatment method for wastewater (Bouwer \& Chaney, 1974); (ii) use of marginal water as an available water source for agriculture (Bouwer \& Idelovitch, 1987; Al-Jaloud et al., 1995; Tanji, 1997) - a sector demanding $\sim 70 \%$ of the consumptive water use in Brazil (Hespanhol, 2002); (iii) use of TSE as nutrient source (Bouwer \& Chaney, 1974; VazquezMontiel et al., 1996) associated with mineral fertilizer savings and high crop yields (Smith \& Peterson, 1982; Feigin et al., 1991).

The soil-plant system, if adequately managed, encourages retention of effluent components mainly due to the incorporation of elements in the dry matter (DM) of plants (Bouwer \& Chaney, 1974), leading to decreasing element concentrations in ground and surface waters (Feigin et al., 1978). Harvest and removal of plant material withdraw the accumulated elements, which further contribute to prevent leaching of elements, mainly nitrogen $(\mathrm{N})$ and phosphorus $(\mathrm{P})$ and enrichments in the subsoil solution and the groundwater concentrations (Quin \& Forsythe, 1978; Hook, 1981). Although irrigation with TSE may mitigate the damage and utilization of natural water resources and enables the diversion of nutrients from waterbodies, it may result in risks that need to be considered in more detail, particularly in the tropics (Fonseca, 2005).

Focussing on agronomical-environmental aspects the objectives of this text were to present an overview of the effects of TSE irrigation on yield production and plant nutrition (annual crops, orchards, forests and forages) as well as on chemical, physical and microbiological soil characteristics. Moreover, indications for further research approaches in Brazil for a sustainable future use of TSE in agro-systems are given.

\section{SEWAGE TREATMENT IN STABILIZATION PONDS AND EFFLUENT DISPOSAL TO THE SOIL-PLANT SYSTEM}

The sewage treatment process using stabilization ponds has been widely used in rural communities and small to medium-sized cities, in areas with warmer climate and no land limitation (Feigin et al., 1991). Also in Brazil this system represents a popular treatment method because of construction and operation simplicity, cost effectiveness, low maintenance requirements and low energy requirements (Von Sperling,
1996). The treatment process produces two residue types: (i) the biosolids (sewage sludge, which is not object of this review) and (ii) the treated sewage effluent (TSE).

The stabilization pond system (also known as the Australian system) is usually divided in two different stages (Pescod, 1992). The first stage takes place in the anaerobic ponds (primary treatment) which are mainly designed for the reduction of the biochemical oxygen demand (BOD) and removal of organic and inorganic solids, greases and oils (Feigin et al., 1991). In these ponds the degradation of organic matter is slow, resulting in odour nuisance due to the formation of hydrogen sulphide. In the final stage of the anaerobic process acidogenic and methanogenic phases occur releasing methane, hydrogen and carbon dioxide (Léon Suematsu \& Moscoso Cavallini, 1999).

The secondary stage (secondary treatment), which takes place in the facultative ponds, is considered as the most important phase in the wastewater treatment process (Feigin et al., 1991). The facultative ponds are larger in area, relatively shallow and predominantly characterized by oxidation processes at the surface and anaerobic processes in depth. During the secondary stage in the facultative ponds most of the remaining organic matter is removed through a coordinated algal-bacterial mutualism. The algae supply the oxygen (by photosynthesis) for the bacteria (aerobic or facultative) to oxidize the organic compounds in the wastewater, and the bacteria provide, by degradation of organic wastes, nutrients and $\mathrm{CO}_{2}$ for the algae to be fixed into new cellular material. The result of this biological process is to convert the organic content of the effluent to more stable forms (Léon Suematsu \& Moscoso Cavallini, 1999).

The liquid product originated from stabilization pond systems is referred to as secondary-treated sewage effluent (STSE). However, the STSE normally does not meet the water quality standards for the disposal as surface waters (Von Sperling, 1995). The characteristics of STSE are in Table 1. The discharge of STSE into superficial streams can cause serious environmental damages such as eutrophication of river systems and is condemned due to environmental, legal and social constraints (Bouwer \& Chaney, 1974; Bond, 1998). The search for alternatives to resolve the environmental problems caused by effluent disposal have been objective of various studies (Bouwer \& Chaney, 1974; Feigin et al., 1991; Cameron et al., 1997; Bond, 1998; Toze, 2006).

One of the alternatives to tackle the problem of adverse effects of TSE would be the use of a tertiary treatment stage. This is however a costly technology, which may exceed one million dollars, depend- 
Table 1 - Characteristics of treated sewage effluents used in scientific studies in the world and in Brazil (Viçosa, MG; Lins, $\mathrm{SP})$.

\begin{tabular}{|c|c|c|c|}
\hline Constituent & World* & Viçosa ${ }^{* *}$ & Lins ${ }^{* * * *}$ \\
\hline \multicolumn{4}{|c|}{ (n } \\
\hline Total solids & $400-1200$ & 528.0 & $571.0 \pm 52.5$ \\
\hline Biological oxygen demand & $10-80$ & - & $77.8 \pm 46.8$ \\
\hline Chemical oxygen demand & $30-160$ & - & $180.5 \pm 91.7$ \\
\hline Total carbon & $10-30$ & - & $49.4 \pm 8.0$ \\
\hline Alkalinity (as $\mathrm{HCO}_{3}^{-}$) & $200-700$ & - & $301.4 \pm 60.8$ \\
\hline Total-N & $10-50$ & $48.0 \pm 32.3$ & $31.9 \pm 5.8$ \\
\hline $\mathrm{H}_{2} \mathrm{PO}_{4}{ }^{2-}-\mathrm{P}$ & $4.2-9.7$ & $12.6 \pm 10.5$ & $4.3 \pm 1.1$ \\
\hline $\mathrm{K}$ & $10-40$ & $32.3 \pm 6.6$ & $16.6 \pm 1.8$ \\
\hline $\mathrm{Ca}$ & $20-120$ & $13.9 \pm 4.6$ & $8.1 \pm 1.1$ \\
\hline $\mathrm{Mg}$ & $10-50$ & $3.2 \pm 0.9$ & $1.9 \pm 0.5$ \\
\hline $\mathrm{SO}_{4}{ }^{2-}-\mathrm{S}$ & 62 & - & $4.9 \pm 1.4$ \\
\hline $\mathrm{Na}$ & $50-250$ & $43.2 \pm 10.7$ & $145.8 \pm 31.3$ \\
\hline B & $<1$ & - & $0.17 \pm 0.09$ \\
\hline $\mathrm{Cu}$ & 0.04 & $0.39 \pm 0.42$ & $<0.01$ \\
\hline $\mathrm{Fe}$ & 0.33 & $5.18 \pm 2.35$ & $0.08 \pm 0.06$ \\
\hline $\mathrm{Mn}$ & $0.20-0.70$ & $0.12 \pm 0.06$ & $0.02 \pm 0.01$ \\
\hline $\mathrm{Zn}$ & 0.04 & $0.08 \pm 0.04$ & $0.02 \pm 0.01$ \\
\hline $\mathrm{pH}$ & $7.8-8.1$ & $7.23 \pm 0.27$ & $7.51 \pm 0.34$ \\
\hline Electrical conductivity, in $\mathrm{dS} \mathrm{m}^{1}$ & $1.0-3.1$ & $0.56 \pm 0.03$ & $0.86 \pm 0.12$ \\
\hline Sodium adsorption ratio ${ }^{¥}$, in $\left(\mathrm{mmol} \mathrm{L}^{-1}\right)^{0.5}$ & $4.5-7.9$ & $3.03 \pm 0.90$ & $11.94 \pm 2.91$ \\
\hline
\end{tabular}

*Data derived from Bouwer \& Chaney (1974), Asano \& Pettygrove (1987), Feigin et al. (1991) and Pescod (1992). ${ }^{* *}$ Data derived from Medeiros et al. (2005). ${ }^{* * *}$ Data derived from Fonseca et al. (2007). ${ }^{¥}$ Sodium adsorption rate $\rightarrow S A R=N a / \sqrt{C a+M g}$, where Na, Ca and $\mathrm{Mg}$ are given in $\mathrm{mmol} \mathrm{L}^{-1}$.

ing on the volume of wastewater to be treated. Particularly in Brazil, the implementation of a tertiary treatment is restricted by (i) absence of national policies for sewage treatment over the long term (Von Sperling, 1995); and (ii) absence of at least one of the sanitation units (general network, sanitary facilities and garbage collection) in $43.5 \%$ of the permanent households in Brazil (Brasil, 2001).

On the other hand, various studies in other countries have shown that soil application of TSE as water and nutrient source for agricultural irrigation represents a low cost alternative (Asano et al., 1996) and is applicable either in dry regions or in humid regions (Bouwer \& Chaney, 1974). Hence, the application of TSE to the soil-plant system may mitigate the scarcity of water resources and the discharge of nutrients to waterbodies by using soil and plants as natural filters (Pollice et al., 2004).

Aside from economical benefits (Darwish et al., 1999) acquired for diverse climatic and soil conditions (Feigin et al., 1991; Cameron et al., 1997; Bond, 1998), crop irrigation with TSE constitutes an ecologically sound method for the disposal of effluents into the environment (Toze, 2006). Moreover, the TSE irrigation practice addresses some important questions discussed at the United Nations Conference on Development and the Environment in Rio de Janeiro, in 1992. These included wastewater discharge to natural waterbodies, sustainable nutrition of plants and mitigation of freshwater use for agricultural purposes (Agenda 21, 1996). Hence, crop irrigation with TSE may contribute to a sustainable development of our environment.

However, the efficiency of the soil-plant system receiving TSE as well as the viability of this practice and the ability to use the nutrients contained in the TSE are dependent on the following factors:

a) Microbiological quality (Bouwer \& Chaney, 1974; Feigin et al. 1991; Westcot, 1997) and chemical characteristics of effluent (Bouwer \& Idelovitch, 1987), including salinity risk (Mujeriego et al., 1996), sodicity risk (Bond, 1998), trace element (Tanji, 1997) and nitrate $\left(\mathrm{NO}_{3}^{-}\right)$concentrations as well as the predominant $\mathrm{N}$ - form in the effluent (Jordan et al., 1997); 
b) Availability of water sources and environmental conditions (Al-Nakshabandi et al., 1997; Shahalam et al., 1998);

c) Adequacy of irrigation technology and effluent quality (Oron et al., 1999; Bouwer \& Idelovitch, 1987) as well as topography of the area (Quin, 1978);

d) Effluent quantity (Hayes et al., 1990b) and frequency of effluent application (Janssen et al., 2005);

e) Nutrient concentrations in effluent (Janssen et al., 2005) and quantity of mineral fertilizers applied (Bouwer \& Idelovitch, 1987);

f) Chemical (Bond, 1998), physical (Balks et al., 1998), microbiological (Friedel et al., 2000) and biochemical soil characteristics (Speir, 2002), as well as natural soil fertility (Janssen et al., 2005);

g) Type and target yield of the crop in question (Janssen et al., 2005);

h) Social-economical conditions and technology level of the farmers (Agunwamba, 2001).

The choice of crops for TSE irrigation was found to be the principal factor for the sustainability of effluent irrigation because certain crops can be irrigated with wastewater without negative implications on yield (Bouwer \& Idelovitch, 1987). Moreover, plants can control the $\mathrm{N}$ loss in the soil-plant system by minimizing $\mathrm{N}$ leaching (Barton et al., 2005). In this context, the crops chosen to receive TSE irrigation should present the following characteristics: (i) high water and $\mathrm{N}$ demands; (ii) good potential use; (iii) marketable and economically viable (Segarra et al., 1996). The efficient use of nutrients by the plants, mainly N, implies in lower mineral fertilizer costs, energy savings and reduction of pollution risks to the groundwater.

Considering the aspects mentioned above and from the agronomical-environmental point of view, promising results of TSE irrigation can be expected for three main agro-systems: (i) annual crops, (ii) orchards and forests; and (iii) forage crops.

\section{EFFECTS OF TREATED SEWAGE EFFLUENT IRRIGATION ON ANNUAL CROPS}

The irrigation of cotton (Gossypium spp.) with TSE mainly by drip irrigation (Feigin et al., 1984) represents a common practice in different countries (Day et al., 1981; Bielorai et al., 1984; Oron et al., 1999). For instance, a study in Israel indicated that the input of $\mathrm{N}$ of about $200 \mathrm{~kg} \mathrm{~N} \mathrm{ha}^{-1}$ year $^{-1}$ due to TSE irrigation exceeded the mineral-N fertilizer (MNF) needs (120 to $180 \mathrm{~kg} \mathrm{~N} \mathrm{ha}^{-1}$ year $^{-1}$ ) usually applied in cotton production (Feigin et al., 1978). Aside from higher $\mathrm{NO}_{3}^{-}-\mathrm{N}$ in the soil solution (Feigin et al., 1978), the excess of $\mathrm{N}$ in the soil-plant system resulted in (i) increase of $\mathrm{N}$ leaf concentrations during the vegetative and growth period of cotton; and (ii) lowering of lint percentage (Bielorai et al., 1984). The problem of $\mathrm{N}$ excess in cotton due to TSE irrigation was also indicated in studies in USA and was solved by means of a mixture (1:1) of TSE and freshwater (Day et al., 1981). The combination of adequate irrigation quantities and the control of $\mathrm{N}$ contents have provided better quality of the fibres (Day et al., 1981) and cotton yield (Feigin et al., 1984). Moreover, TSE irrigation can supply up to $100 \%$ of potassium $(\mathrm{K})$ needs to cotton, however, under conditions where the soil represents high available K concentrations (Feigin et al., 1991).

Also oilseeds [Brassica napus (L.) cv. canola and Brassica campestris L. cv. rapeseed] had positive responses to effluent- $\mathrm{N}$ and other nutrients present in TSE (Al-Jaloud et al., 1996). Oilseeds irrigated with TSE have been found to be interesting receptor crops due to both industrial use and MNF savings. Al-Jaloud et al. (1996) reported that for a mean yield of $3.8 \mathrm{t} \mathrm{ha}^{-1}$ (maximum technical efficiency) TSE irrigation (containing $40 \mathrm{mg}$ mineral- $\mathrm{N} \mathrm{L}^{-1}$ ) can save $150 \mathrm{~kg} \mathrm{~N} \mathrm{ha}^{-1}$ of the recommended $\mathrm{N}$ fertilizer rate.

With regard to winter grains different results after TSE irrigation were found. On one hand, Day et al. (1962) showed that yields and crude protein (CP) concentrations in oat (Avena sativa L.), barley (Hordeum vulgare L.) and wheat (Triticum aestivum L.) were not altered by TSE irrigation. On the other hand, Day et al. (1963) observed that TSE irrigation caused excess of $\mathrm{N}$ in barley resulting in an increase of the $\mathrm{CP}$ concentration in the grain and, consequently, in a reduction of the malt quality. However, these adverse outcomes could also be diminished using a mixture (1:1) of TSE and freshwater (Day et al., 1963). In another study, Hussain \& Al-Jaloud (1998) verified after TSE irrigation $\left(40 \mathrm{mg}\right.$ mineral- $\left.\mathrm{N} \mathrm{L}^{-1}\right)$ high yields of barley associated with savings of 50-75\% (100-150 $\mathrm{kg} \mathrm{N} \mathrm{ha}{ }^{-1}$ ) of the recommended MNF rates.

Day et al. (1974) observed after TSE irrigation of wheat increases of culm diameter, total fibres and $\mathrm{CP}$ concentrations, grain yield and nitrogen use efficiency (NUE). On the other hand, in further experiments on wheat, Day et al. (1975) found no changes in (i) plant height; (ii) seeds per head; (iii) weight of 1,000 seeds; and (iv) total fibres, $\mathrm{CP}$ and acid-soluble nucleotides concentrations. However, Day et al. (1975) emphasized that in these studies the number of heads per area increased associated with higher grain yields. Subsequent studies (Day et al., 1979) on the effect of mixing TSE and freshwater showed increases of heads 
per area, weight of 1,000 seeds, and grain and DM yields. Hussain et al. (1996) determined in wheat experiments irrigated with TSE (containing $20 \mathrm{mg}$ mineral-N L ${ }^{-1}$ ): (i) increase of wheat yield; (ii) increase of NUE; (iii) positive interactions between effluent- $\mathrm{N}$ and some other elements essential for plant growth; and (iv) savings of $1 / 3$ of the recommended $\mathrm{N}$ fertilizer rates $\left(300 \mathrm{~kg} \mathrm{~N} \mathrm{ha}^{-1}\right)$ without loss of grain and DM yields. Based on these results it was concluded that TSE can be considered as a partial nutrient source for wheat and as an efficient alternative to substitute freshwater for irrigation (Day et al., 1974; 1975; 1979; Hussain et al., 1996) in order to maintain or increase yield, grain quality and NUE.

Few studies were carried out on TSE application for sunflower (Helianthus annuus L.). Bange et al. (1997) observed higher use efficiency of solar radiation due to increase in leaf $\mathrm{N}$ concentrations resulting from elevated $\mathrm{N}$ availability in the soil after TSE irrigation. Moreover, Gadallah (1994) showed that sunflowers irrigated with TSE: (i) increased the leaf concentrations of calcium $(\mathrm{Ca})$, magnesium $(\mathrm{Mg})$ and chloride $(\mathrm{Cl})$; (ii) increased root concentrations of zinc $(\mathrm{Zn})$, manganese $(\mathrm{Mn})$ and sodium $(\mathrm{Na})$; and (iii) increased and decreased $\mathrm{Na}$ and $\mathrm{K}$ accumulation in the plants.

For sorghum [Sorghum bicolor (L) Moench] Day \& Tucker (1977) reported that TSE irrigation compared to conventional water irrigation did not show differences for the following parameters: (i) plant height; (ii) tillers per plant; (iii) weight of 1,000 seeds; (iv) $\mathrm{CP}$ concentration; and (v) leaf length. However, the grain yield was higher in the TSE treated areas. Moreover, Al-Jaloud et al. (1995) determined in sorghum increases in leaf $\mathrm{N}, \mathrm{Ca}, \mathrm{Mg}$ and $\mathrm{Na}$ concentrations, and decreases in leaf $\mathrm{P}$ and $\mathrm{K}$ concentrations, emphasizing that the elements contained in the TSE were responsible for 74 to $97 \%$ of the nutrient variability in the plants. Generally, the results have indicated a positive response of sorghum to effluent irrigation due to the presence of nutrients (mainly N) in TSE (Day \& Tucker, 1977; Al-Jaloud et al., 1995).

For maize (Zea mays L.) increasing grain (Vazquez-Montiel et al., 1996; Oron et al., 1999), DM (Al-Jaloud et al., 1995) and silage yield (Overman, 1981) were observed after TSE irrigation. On the other hand, Feigin et al. (1981) found lower NUE and attributed it to losses of effluent- $\mathrm{N}$ by volatilization. The low effluent-N efficiency in maize can induce nutritional deficiency and/or yield losses because the development of the corn ear depends on an adequate storage of nutrients in leaves and stems (Overman et al., 1995). On the other hand, Vazquez-Montiel et al. (1996) found after TSE irrigation increases in N and
$\mathrm{P}$ uptake rates associated with higher crop yields; however, in this study maize received mineral fertilization during sowing. Another experiment conducted with maize and TSE irrigation presented: (i) increases in N, $\mathrm{P}, \mathrm{K}, \mathrm{Mg}, \mathrm{Na}, \mathrm{Mn}, \mathrm{Zn}$, copper $(\mathrm{Cu})$ and molybdenum (Mo) concentrations in leaves; (ii) 82 to $99 \%$ of the variability of the mineral concentrations in the plants were directly influenced by the TSE quality; and (iii) despite the elevated $\mathrm{Na}$ concentrations in the plants the DM yields increased with higher Na concentration and salinity of the effluent (Al-Jaloud et al., 1995). In a greenhouse experiment with maize Fonseca et al. (2005a; 2005b) observed after TSE irrigation (TSE originated from Lins $\left(22^{\circ} 21^{\prime} \mathrm{S}, 49^{\circ} 50^{\prime} \mathrm{W}\right)$, São Paulo State, Brazil): (i) complete substitution of the irrigation water used and partially of $\mathrm{N}$-fertilization, but no adequate nutrition of maize without supply of mineral fertilizers (ii) no increase of DM yield after complete fertilization despite higher plant $\mathrm{N}$ and $\mathrm{P}$ contents; (iii) no changes in $\mathrm{Cu}, \mathrm{Fe}, \mathrm{Mn}$, boron (B) and sulphur (S) accumulation in plant shoots when plants were properly fertilized; (iv) slight decrease in $\mathrm{Zn}$ accumulation; (v) distinct effects on $\mathrm{Na}$ dynamics showing a 100-fold increase in the plants; and (vi) no impacts on plant cadmium $(\mathrm{Cd})$, chromium $(\mathrm{Cr})$, lead $(\mathrm{Pb})$ and nickel $(\mathrm{Ni})$ accumulation. Generally, it is suggested that the increase in maize yields resulted from the following items: (i) increase of TSE application rate causing higher nutrient inputs (Overman, 1981); (ii) higher uptake and accumulation of nutrients, mainly of $\mathrm{N}$ and P (Vazquez-Montiel et al., 1996); and (iii) occurrence of macro- and micronutrients in the effluent which can neutralize the undesirable effect of high $\mathrm{Na}$ concentrations in TSE (Al-Jaloud et al., 1995). Moreover, the often described antagonistic effect between $\mathrm{Na}$ and $\mathrm{K}$ was more pronounced under low $\mathrm{K}$ concentrations in soil (Fonseca et al., 2005b).

\section{EFFECTS OF TREATED SEWAGE EFFLUENT IRRIGATION IN ORCHARDS AND FOREST PLANTATIONS}

Orchards have been successfully irrigated with TSE in various regions of the world such as Australia (Johns \& McConchie, 1994a; 1994b), Spain (Reboll et al., 2000), USA (Maurer \& Davies, 1993; Zekri \& Koo, 1994) and Israel (Lurie et al., 1996) including studies on banana (Musa spp.), citrus (Citrus sp.) and nectarine (Prunus persica L.). Johns \& McConchie (1994a) found that the banana yield increased about $10 \%$ after TSE irrigation. The authors verified moreover that (i) TSE irrigation at a rate of $600 \mathrm{~mm}$ supplied about $20 \%$ of plant $\mathrm{N}$ requirement $\left(350 \mathrm{~kg} \mathrm{~N}^{-1}\right)$ without causing environmental disadvantage (Johns \& McConchie, 1994b); (ii) despite higher $\mathrm{Na}$ concentra- 
tions in the soil, the leaf $\mathrm{Na}$ concentrations were not affected in the same proportion (Johns \& McConchie, 1994a); and (iii) plant element concentrations showed increases of $225 \% \mathrm{Na}, 81 \% \mathrm{~B}, 43 \% \mathrm{Cu}, 26 \% \mathrm{Cl}$ and $16 \% \mathrm{~N}, \mathrm{P}$ and $\mathrm{K}$ and a decrease of $\mathrm{Ni}$ due to the increase in soil pH (Johns \& McConchie, 1994b). In a TSE irrigation study on coconut palm (Cocos nucifera L.), Fitzpatrick et al. (1986) observed accelerated growth, leading to positive results on yield and mineral fertilizer economy without deleterious effects on the environment.

Application of TSE in forest plantations have become a popular alternative of water reuse because of: (i) not being part of the food chain; (ii) providing a green image; (iii) a higher water use than other crops and hence, requiring less land for a given volume of effluent; and (iv) $\mathrm{N}$ and $\mathrm{C}$ storage in biomass (mainly in wood) over the long-term that represents the major mechanism for retention of the elements in the ecosystem (Jordan et al., 1997; Smith \& Bond, 1999). TSE application on forests, especially in eucalyptus (Eucalyptus sp.) and pine (Pinus sp.) plantations has been extensively practiced in Australia and New Zealand (Cameron et al., 1997; Bond, 1998; Speir, 2002). Cromer et al. (1984) observed after three years of TSE irrigation in a pine plantation increasing contents of $\mathrm{N}, \mathrm{P}$ and $\mathrm{K}$ in the pine foliage. Polglase et al. (1995) found increasing $\mathrm{N}$ uptake rates in pine trees associated with positive effects on tree growth. Another study conducted by Falkiner \& Smith (1997) revealed no negative effects on the growth of eucalyptus and pine despite increasing soil salinity. This aspect can probably be attributed to the significant amount of nutrients in TSE (Bouwer \& Chaney, 1974; Feigin et al., 1991; Pescod, 1992) that can mitigate the adverse effects caused by $\mathrm{Na}$ and other elements (Al-Jaloud et al., 1995).

The TSE irrigation in forest plantations was found to be favourable until the canopy closes (Hook $\&$ Kardos, 1978). Subsequently, the natural biogeochemical recycling represents the main responsible factor for nutrient supply to the soil-forest system (Gonçalves et al., 2000). Therefore, the external nutrient input to the soil-forest system by TSE irrigation can: (i) influence mineralization and the turnover of soil organic matter (SOM) affecting directly the carbon (C) and N cycles (Polglase et al., 1995; Falkiner \& Smith, 1997); and (ii) cause destabilization of the ecosystem by increasing $\mathrm{NO}_{3}^{-} \mathrm{N}$ concentration in the soil solution and the groundwater (Hook \& Kardos, 1978).

\section{EFFECTS OF TREATED SEWAGE EFFLUENT IRRIGATION ON FORAGE PLANTS}

Forage plants have been chosen for TSE irrigation approaches because of the long growing season associated with high seasonal evapotranspiration, the high nutrient uptake capacity, and the ability to prevent erosion processes (Bole \& Bell, 1978). Favourable effects of TSE as water and nutrient source in soil-forage plant systems (Day \& Tucker, 1960; Fonseca et al., 2007) have been reported in various studies. Aside from a work performed by Day \& Tucker (1959) who found 22\% lower yields of forage barley (attributed to the presence of detergents and high concentrations of soluble salts in the effluent), in general, increases in DM and/or CP yields were reported for: (i) alfalfa (Medicago sativa L.) (Bole \& Bell, 1978; Darwish et al., 1999; Grattan et al., 2004); (ii) ryegrass (Lolium perenne L.) - white clover pasture (Trifolium repens L.) (Quin \& Woods, 1978); (iii) bermudagrass (Cynodon dactylon) (Hayes et al., 1990b; Grattan et al., 2004); (iv) 'Tifton 85' hybrid bermudagrass (Cynodon dactylon Pers. X C. niemfuensis Vanderyst) (Fonseca et al., 2007); (v) Rhodes grass (Chloris gayana Kunth) (Feigin et al., 1978); (vi) kikuyugrass (Pennisetum cladestinum Hochst. Ex Chiov) (Grattan et al., 2004); (vii) napier grass (Pennisetum purpureum) (Jeyaraman, 1988); and (viii) forage corn (Zea mays L.) (Overman \& Nguy, 1975; Overman, 1981; Mohammad \& Ayadi, 2004).

Due to the fact that $\mathrm{Na}$ concentrations are higher in TSE as compared to conventional irrigation water (Feigin et al., 1991; Pescod, 1992), higher qualitative-quantitative crop yields were observed for $\mathrm{C}_{4}$ natrophilic species ${ }^{\S}$ irrigated with effluent (Grieve et al., 2004). However, the increase of $\mathrm{Na}$ concentrations in forage plants represents a desirable effect leading to an increase of the forage quality associated with a higher acceptability by animals (Marschner, 1995).

In terms of nutritional aspects in forage plants, Bole \& Bell (1978) reported thar after TSE irrigation of alfalfa no alterations were found in the $\mathrm{Mg}, \mathrm{Cu}, \mathrm{Mn}$, $\mathrm{Zn}$ and iron $(\mathrm{Fe})$ concentrations in the plants and concluded an adequate nutrient supply by TSE, except for N. However, the study was carried out on a soil of high natural fertility, with water as the main limiting factor, which was therefore balanced by TSE application. Another experiment on alfalfa using effluents rich in $\mathrm{Cr}$ and $\mathrm{Pb}$ resulted in increasing contents of these elements in the plants (Flores Tena et al., 1999). In forage corn, Overman \& Nguy (1975) verified after TSE irrigation (containing $37 \mathrm{mg}$ total- $\mathrm{N} \mathrm{L}^{-1}$ ) increased DM

\footnotetext{
${ }^{\S}$ Natrophilic species are plants which readily concentrate $\mathrm{Na}$ in their leaves, whereas natrophobic species concentrate Na mainly in their roots or lower stem tissue (Smith et al., 1978).
} 
yield, $\mathrm{N}$ uptake rates and $\mathrm{CP}$ concentration. Moreover, the study showed that in sandy soils the recovery percentage of $\mathrm{N}$ was higher at lower application rates (50 $\mathrm{mm}$ week $\left.^{-1}\right)$, whereas at higher application rates (200 $\mathrm{mm}$ week $^{-1}$ ) the efficiency of $\mathrm{N}$ recovery from the effluent was lower $(\leq 50 \%)$ causing increased $\mathrm{N}$ concentrations in the groundwater. In a long term study (16 years) on ryegrass, Quin \& Syers (1978) found no changes of $\mathrm{Cu}, \mathrm{Mn}, \mathrm{Ni}, \mathrm{Zn}, \mathrm{Cd}, \mathrm{Cr}, \mathrm{Pb}$, cobalt (Co) and strontium $(\mathrm{Sr})$ concentrations in leaves after TSE irrigation.

Rhodes grass attracted attention in TSE irrigation because the plant responded positively to high application rates and frequencies (Feigin et al., 1978). In this context, Linden et al. (1981) reported that higher irrigation frequencies caused increasing NUE associated with lower $\mathrm{N}$ leaching in soil. On the other hand, in a comparative study between Rhodes grass, cotton and sugar beet [Beta vulgaris (L.) ssp. Vulgaris], Rhodes grass was more efficient in the uptake of effluent- $\mathrm{N}$ resulting in $<10 \mathrm{mg} \mathrm{L}^{-1}$ of $\mathrm{NO}_{3}^{-}-\mathrm{N}$ in the soil solution after $\mathrm{N}$ input of $500 \mathrm{~kg} \mathrm{ha}^{-1}$ year $^{-1}$ (Feigin et al., 1978).

In a experiment two year with the 'Tifton 85' hybrid bermudagrass, Fonseca et al. (2007) observed that: (i) TSE can efficiently substitute potable water for pasture irrigation; (ii) the substitution of potable water by TSE associated with recommended N-fertilization (520 kg N ha ${ }^{-1}$ year $\left.^{-1}\right)$ increased grass DM yield and $\mathrm{CP}$ content; and (iii) because of the $\mathrm{N}$ content in TSE (containing $31.9 \mathrm{mg}$ total- $\mathrm{N} \mathrm{L}^{-1}$ ) 32 to $81 \%$ less MNF was needed to obtain the maximum DM yield as compared to irrigation with potable water and recommended fertilization that corresponds to annual savings of 179 to 450 USD per hectare. However, the responses of Tifton 85 bermudagrass to TSE irrigation and the MNF economy were dependent on rainfall intensities and the applied irrigation amount (Fonseca et al., 2007).

\section{ENVIRONMENTAL IMPLICATIONS AND MA- JOR CHANGES IN CHEMICAL, PHYSICAL AND MICROBIOLOGICAL SOIL CHARACTER- ISTICS}

Aside from beneficial effects, TSE irrigation practice can cause environmental risks such as the potential to transmit diseases since pathogens in the effluent can survive in the soil-plant system. In this context, the actual risk, however, is related to whether this survival time is long enough to allow transmission to a susceptible host (Westcot, 1997). The factors controlling transmission of disease are agronomic, such as the crop grown, the irrigation method used to apply the wastewater, and the management and harvesting prac- tices used. The largest contamination risk through enteric pathogens is being caused by the use of untreated wastewater in agricultural irrigation, affecting farm workers and consumers (Santamaría \& Toranzos, 2003).

Protective measures for public health have to include an integration of diverse control alternatives such as: (i) crop restrictions (Pescod, 1992); (ii) secondary treatment of wastewater (Feigin et al., 1991) followed by chlorination processes (Bouwer \& Idelovitch, 1987); (iii) control of TSE application, human exposition and hygiene (Pescod, 1992); and (iv) reduction of contamination risks e.g. by sun-dried forage as used in hay production systems (Westcot, 1997). Hence, for sustainable use of TSE in agro-systems the monitoring of the effluent quality (Bouwer \& Chaney, 1974; Tanji, 1997), especially from the microbiological point of view (Westcot, 1997) is of fundamental importance. More detailed information on this aspect can be found in Blumenthal et al. (2000). The authors discuss different approaches to establish guidelines for the evaluation of the microbiological quality of treated wastewater that is intended for agricultural irrigation use.

Besides the still existing problems of public acceptance (Pollice et al., 2004), crop irrigation with TSE was found to change chemical (Bond, 1998), physical (Balks et al., 1998), microbiological (Friedel et al., 2000) and biochemical characteristics of soils (Speir, 2002), as well as environmental conditions (AlNakshabandi et al., 1997). The magnitude of the changes in the soil-water-plant-human-environment system depends on the local conditions such as soil type, plant species, climate, water sources, and quality/quantity of the TSE applied to the production system (Hayes et al, 1990b; Cameron et al., 1997; Bond, 1998; Shahalam et al., 1998; Mohammad \& Ayadi, 2004). These changes can implicate in significant impacts (Mohammad \& Mazahreh, 2003) or no (Mancino \& Pepper, 1992; Wang et al., 2003) on soil quality.

In relation to the total carbon (TC), total nitrogen (TN) concentrations and microbial activity in soils, Quin \& Woods (1978), Mancino \& Pepper (1992) and Friedel et al. (2000) verified increases due to the $\mathrm{N}$ and $\mathrm{C}$ input by TSE. The increases following TSE irrigation have mainly been observed in long-term experiments, as reported by Quin \& Woods (1978), Friedel et al. (2000) and Ramirez-Ruentes et al. (2002). On the other hand, decreases in TC and TN concentrations were reported in various other studies and were attributed to following factors: (i) predominance of the effluent- $\mathrm{N}$ in the mineral form (Bouwer \& Chaney, 1974; Feigin et al., 1991); (ii) fast mineralization of the effluent organic $\mathrm{N}$ fraction, consisting predomi- 
nantly of dead algae (Snow et al., 1999); (iii) maintenance of ideal conditions for mineralization of organic matter such as humidity (Myers et al., 1982), temperature (Artiola \& Pepper, 1992), re-supply of $\mathrm{O}_{2}$ (Stanford \& Smith, 1972); (iv) low C/N ratio of TSE (Bouwer \& Chaney, 1974; Feigin et al., 1991; Fonseca et al., 2007); and (v) increase of the microbial activity encouraging SOM decomposition (Polglase et al., 1995; Barton et al., 2005) associated with probable priming effects due to high input of effluent-N (Fonseca, 2005).

Priming effects are strong short-term changes in the turnover of SOM caused by comparatively moderate treatments of the soil. In the course of priming effects large amounts of $\mathrm{C}, \mathrm{N}$ and other nutrients can be released or immobilized in soil in a very short time (Kuzyakov et al., 2000). Assuming that extra loss of soil $\mathrm{C}$ is caused by a priming action, the probable explanation is that there is a buildup of a large and vigorous population of microorganisms when energy material is added to the soil and that these microorganisms subsequently produce enzymes that attack the native SOM (Stevenson, 1986). Soil microbial biomass plays a key role in the processes leading to the real priming effects (Kuzyakov et al., 2000). Moreover, the input of $\mathrm{N}$ causes enhanced mineralization of native humus $\mathrm{N}$ though a priming action and plants growing on treated soil develop a more extensive root system, thereby permitting better utilization of untagged soil $\mathrm{N}$ by the plant (Stevenson, 1986). In this context, Barton et al. (2005) studied intact grassed soil cores of four soil types in New Zealand, irrigated with TSE (50 mm per week) over two years. The study revealed that TSE irrigation resulted in: (i) priming effects in two of these soils (a well-drained soil with a high allophane content and a well-drained soil formed in a sand dune); and (ii) increase of $\mathrm{N}$ leaching due to increased leaching of native soil organic N. From this follows that changes in soil microbiology after TSE irrigation are associated with increasing microbial activity and alterations in the populations of functional microorganism groups (Ibekwe et al., 2003; Speir, 2002), resulting from the input of nutrients and soluble organic $\mathrm{C}$ immediately available to microorganisms.

TSE application has also revealed increments in biochemical soil properties such as microbial biomass, basal respiration, specific respiration activity or metabolic quotient and hydrolytic enzyme activities. However, these parameters were highly sensitive to changes in their environment, e.g. noticeable alterations in the composition and the quantity of the TSE applied (Speir, 2002). By means of denaturing gradient gel electrophoresis (DGGE) it was shown that changes in TSE application resulted in significant alterations of the genetic diversity of microorganisms in soil. Oved et al. (2001) observed changes in the composition of ammonia-oxidizing bacteria populations involved in the nitrification process. The study revealed that the genus Nitrosomonas dominated in TSE irrigated soils whereas Nitrospira predominated in untreated soils.

In compliance with the stimulation of microbial activity, the use of TSE in agro-systems tends to increase the density of microorganism groups as total bacteria, actinomycetes and fungi (Mekki et al., 2006). In this context, Kern \& Idler (1999) reported an increase of ammonifying bacteria which reflect organic $\mathrm{N}$ mineralization. In contrast, the chemolithotrophic ammonia-oxidizing bacteria presented a different behaviour. After addition of organic compounds (via TSE or organic residues), the chemolithotrophic ammonia-oxidizing bacteria were subject to a competitive disadvantage as compared to the heterotrophic microbial communities, leading to a decrease of the population density of autotrophic ammonia-oxidizing bacteria (Acea \& Carballas, 1999). However, to date, few studies have focused on the relation between TSE disposal on soil and the activity of chemolithotrophic bacteria in the nitrification process (Mekki et al., 2006; Ibekwe et al., 2003).

On the other hand, the addition of organic compounds by high inputs of soluble effluent-C favours the heterotrophic microbial communities generating $\mathrm{NO}_{3}^{-}$by heterotrophic nitrification (Nurk et al., 2005; Su et al., 2006). These microbial communities are also capable to accomplish denitrification using $\mathrm{NO}_{3}^{-}$and $\mathrm{NO}_{2}^{-}$(nitrite) as electron acceptors resulting in the formation of nitrous oxide $\left(\mathrm{N}_{2} \mathrm{O}\right)$ (McLain \& Martens, 2006). In addition, the $\mathrm{N}$ losses by denitrification after TSE irrigation can also be encouraged by high concentrations of $\mathrm{NO}_{3}^{-}-\mathrm{N}$ and decreasing $\mathrm{O}_{2}$ concentrations in the soil (Bouwer \& Chaney, 1974; Polglase et al., 1995; Schipper et al., 1996). These factors may explain the 2-fold (Schipper et al., 1996) up to 50-fold increases (Friedel et al., 2000) of denitrification rates in TSE irrigated soils. Generally, denitrification can lead to undesirable $\mathrm{N}$-outputs from soils in form of $\mathrm{NO}_{x}, \mathrm{~N}_{2} \mathrm{O}$ which are known as potential gaseous components in the atmosphere contributing to the greenhouse effect. Moreover, $\mathrm{NO}_{\mathrm{x}}$ are characterized as chemical reactive gases which regulate the pro-

\footnotetext{
*Nitrogen oxides, or $\mathrm{NO}_{x}$, is the generic term for a group of highly reactive gases, all of which contain nitrogen and oxygen in varying amounts. Many of the nitrogen oxides are colorless and odorless. However, one common pollutant, nitrogen dioxide $\left(\mathrm{NO}_{2}\right)$ along with particles in the air can often be seen as a reddish-brown layer over many urban areas (USEPA, 1998).
} 
duction of ozone in the troposphere and represent a basic condition for acid rain. $\mathrm{N}_{2} \mathrm{O}$ contributes to the degradation of the stratosphere (Hall \& Matson, 1999).

Another important factor represents the alkalinity of effluents (Table 1) that favours the volatilization of ammonia $\left(\mathrm{NH}_{3}\right)$, leading moreover to $\mathrm{N}$ losses from soils after TSE irrigation. The ammonium $\left(\mathrm{NH}_{4}^{+}\right)$ concentration in the effluent, $\mathrm{pH}$ at the soil surface and temperature are factors which directly interfere with the equilibrium between $\mathrm{NH}_{4}^{+}$and $\mathrm{NH}_{3}$ in the soil solution and the quantity of $\mathrm{NH}_{3}$ that is being volatilized (Smith et al., 1996a). The same authors verified that the loss of $\mathrm{NH}_{3}$ from the soil after TSE application is higher during the day (higher temperatures). They noted moreover, that the volatilization of $\mathrm{NH}_{3}$ can be reduced by frequent application of small quantities of TSE. Although volatilization of $\mathrm{NH}_{3}$ represents an important aspect regarding $\mathrm{N}$ losses from the soil, there is still a lack of studies on its quantification in different agro-systems in Brazil where TSE irrigation is already practiced.

In TSE, $\mathrm{NH}_{4}^{+}-\mathrm{N}$ constitutes normally the predominant $\mathrm{N}$ form. Although nitrification in soils can proceed within hours, $\mathrm{NH}_{4}^{+}$can also be electrostatically adsorbed to the cation exchange complex that may delay microbial transformation processes (Hook, 1981). In this context, Hook \& Kardos (1978) demonstrated in TSE irrigated forest soils higher $\mathrm{N}$ leaching when $\mathrm{NO}_{3}^{-}-\mathrm{N}$ represented the predominant $\mathrm{N}$ form in the effluent. On the other hand, $\mathrm{N}$ leaching was lower when $\mathrm{NH}_{4}^{+}-\mathrm{N}$ was the major $\mathrm{N}$ form in effluent.

Increasing concentrations of mineral-N, particularly of $\mathrm{NO}_{3}^{-} \mathrm{N}$, have been determined in the soil solution after TSE irrigation of annual crops (Feigin et al., 1978), orchards (Johns \& McConchie, 1994b), forage plants (Quin \& Forsythe, 1978; Linden et al., 1981; Lund et al., 1981) and forest plantations (Hook \& Kardos, 1978; Polglase et al., 1995; Magesan et al., 1998; Smith \& Bond, 1999; Speir et al., 1999). The increases in $\mathrm{NO}_{3}^{-} \mathrm{N}$ can be attributed to the following factors: (i) fast transformation of effluent $\mathrm{NH}_{4}^{+}-\mathrm{N}$ and organic- $\mathrm{N}$ to $\mathrm{NO}_{3}^{-} \mathrm{-N}$; (ii) increase of mineralization and nitrification of soil organic nitrogen due to TSE application; and (iii) inadequacy between crop $\mathrm{N}$ requirements and $\mathrm{N}$ input by TSE irrigation. Therefore, the monitoring of $\mathrm{NO}_{3}^{-}-\mathrm{N}$ in the soil solution is crucial because high $\mathrm{NO}_{3}^{-}-\mathrm{N}$ concentrations in soils point to the risk of groundwater contamination affecting negatively the water quality for human consumption (Bouwer, 2000). Excess of $\mathrm{NO}_{3}^{-} \mathrm{N}$ in potable water (and in foods) may lead to infant mortality (methaemoglobinaemia, known as blue baby syndrome) resulting from a reduction of $\mathrm{NO}_{3}^{-}$to $\mathrm{NO}_{2}^{-}$by microorganisms in baby's stomach and in the rumen of animals. In the blood $\mathrm{NO}_{2}^{-}$binds to haemoglobin that prevents binding of oxygen for transport to the cells (Stevenson, 1986).

TSE irrigation did not affect soil $\mathrm{pH}$ due to the high soil buffer capacity (Bouwer \& Idelovitch, 1987). Nevertheless, several studies reported slight increases of soil $\mathrm{pH}$ in different agro-systems irrigated with TSE (Quin \& Woods, 1978; Stewart et al., 1990; Schipper et al., 1996; Falkiner \& Smith, 1997; Fonseca et al., 2005b). The increases in soil $\mathrm{pH}$ have been attributed to: (i) high effluent pH (Stewart et al., 1990); (ii) addition of exchangeable cations and alkalinity by effluent (Falkiner \& Smith, 1997); (iii) increase of denitrification (Friedel et al., 2000) consuming one mol of $\mathrm{H}^{+}$for each mol denitrified $\mathrm{NO}_{3}^{-}$(Bolan et al., 1991); (iv) addition of organic residues to the soil followed by decarboxilation and desamination (organic anions and amino acids) processes consuming protons (Yan et al., 1996); and (vi) interaction of these factors associated with low cation exchange capacity (CEC) of the soil (Stevenson, 1986) as normally found in Brazilian soils (Fonseca et al., 2005b). However, the pH changes are generally of low magnitude (smaller than one unit) without practical importance with regard to nutrient availability (Speir et al., 1999), especially in the acidic soils of Brazil with inherent low natural fertility (Fonseca et al., 2005b).

The input of $\mathrm{P}$ to the soil by TSE irrigation generally does not occur in excess. In the cases of increasing available $\mathrm{P}$ concentrations after TSE irrigation alterations were observed both in the superficial layer (Hortenstine, 1976; Quin \& Woods, 1978) and subsuperficial layer (Latterell et al., 1982; AlNakshabandi et al., 1997; Mohammad \& Mazahreh, 2003) and were more pronounced in experiments carried out over more than five years (Sommers et al., 1979; Zekri \& Koo, 1994; Wang et al., 2003). After harvest and the removal of plant material, the incorporated effluent-P may be removed from the soil-plant system minimizing undesirable effects of elevated $\mathrm{P}$ concentrations in the soil solution (Kardos \& Hook, 1976; Hook, 1981; Fonseca, 2005). Moreover, the specific adsorption capacity of soil to retain $\mathrm{P}$ can contribute to prevent $\mathrm{P}$ leaching from the root zone to deeper layers (Ryden \& Pratt, 1980) and represents a factor to maintain environmental sustainability of the system after TSE irrigation (Falkiner \& Polglase, 1997). In contrast, Hook (1981) and Bond (1998) provided evidence of $\mathrm{P}$ migration in sandy soils after TSE irrigation. However, to date, few studies have focused on the mechanisms controlling migration and retention of $\mathrm{P}$ in areas under TSE irrigation (Falkiner \& Polglase, 1997). Thus, long-term field studies are necessary to understand the processes which control the effluent-P 
dynamics in soil (Bond 1998), especially in soils with variable charges (Fonseca et al., 2005a) that represent the predominant condition in agro-systems in Brazil.

Irrigation with TSE can cause changes in exchangeable $\mathrm{Ca}, \mathrm{Mg}$ and $\mathrm{K}$ concentrations. Increases of exchangeable $\mathrm{Ca}$ concentrations were observed mainly over longer periods in soils under forest plantations (Cromer et al., 1984; Falkiner \& Smith, 1997; Speir et al., 1999) and pastures (Quin \& Woods, 1978). Exchangeable Mg showed increases (Falkiner \& Smith, 1997), decreases (Wang et al., 2003) or negligible alterations (Johns \& McConchie, 1994b; Fonseca et al., 2005b) after TSE irrigation. Also the results on exchangeable K concentrations were contradictory. Johns $\&$ McConchie (1994b) found no TSE effects on exchangeable $\mathrm{K}$ concentrations. Increasing exchangeable $\mathrm{K}$ concentrations were observed by Cromer et al. (1984) and Falkiner \& Smith (1997) in forest soils and in soils cropped with eggplant (Solanum melongena $\mathrm{L}$.) (Al-Nakshabandi et al., 1997). On the other hand, Karlen et al. (1976) and Stewart et al. (1990) noted that TSE application caused decreasing exchangeable $\mathrm{K}$ concentrations due to increasing $\mathrm{Na}$ concentrations in soil. The increase of $\mathrm{Na}$ favoured desorption and leaching of $\mathrm{K}$ that can directly be related to the soil CEC. From this follows that in case of low $\mathrm{K}$ concentration and high concentration of $\mathrm{Na}$ in TSE $\mathrm{K}$ has to be added (via mineral fertilization) to maintain adequate plant K uptake and yields (Karlen et al., 1976). This fact is crucial especially for the tropical soils in Brazil with low CEC and low natural fertility (Fonseca et al., 2005a).

With regard to exchangeable Na concentrations and exchangeable sodium percentage (ESP), generally elevating levels were determined after TSE application, mainly in the surface layer (Cromer et al., 1984). The increases were found both in agricultural and forest soils (Feigin et al., 1991; Pescod, 1992; Bond, 1998) as well as in studies over short (Fonseca et al., 2005b) and long terms (Quin \& Woods, 1978; Balks et al., 1998). In this context, it has been observed: (i) 3.5 to 25-fold increases in soil $\mathrm{Na}$ concentrations, dependent on the TSE application rates (Latterell et al., 1982); (ii) increase of ESP from 3.2 to $9.8 \%$ (Stewart et al., 1990) and from 2 to 25\% (Balks et al., 1998); and (iii) 15.4-fold increase in exchangeable $\mathrm{Na}$ and 13-fold increase in ESP corresponding to $22.5 \%$ of the soil CEC (Fonseca et al., 2005b). Moreover, Johns \& McConchie (1994b) reported after TSE irrigation both increases in soil exchangeable $\mathrm{Na}$ and $\mathrm{Na}$ concentrations in soil solution.

High Na concentrations in soils (sodicity) can cause deterioration of soil physical properties, specifically dispersion of clay with subsequent breakdown of soil structure, blocking of pores, and decrease in soil permeability (Quirk \& Schofield, 1955; Balks et al., 1998; Halliwell et al., 2001). In this context, the increase of exchangeable $\mathrm{Na}$ and ESP in the soil was found to cause alterations (Bond, 1998) or no (Balks et al., 1998) in the hydraulic conductivity. However, the magnitude of the adverse $\mathrm{Na}$ impacts on soil properties are dependent on the efficiency of rain to raise Na leaching (Mancino \& Pepper, 1992; Speir et al., 1999). Hence, monitoring of $\mathrm{Na}$ in the soil-plant-effluent-environment system should be ascribed the same importance as the monitoring of $\mathrm{NO}_{3}^{-}-\mathrm{N}$ (Bond, 1998). High Na concentration in soils irrigated with TSE does not represent the only factor responsible for changes in hydraulic conductivity. The hydraulic constraints as well as the slowing down of the $\mathrm{O}_{2}$ diffusion rates in these soils are also dependent on quality (e.g. concentration of suspended and dissolved solids) and quantity of the TSE applied (Oron et al., 1999). The suspended solids in the effluent (e.g. bacteria flakes, fibrous materials and dead algae) can associate with living bacteria and stimulate the production of polysaccharides and other organic compounds resulting in biological plugging of the surface soil (Bouwer \& Chaney, 1974).

TSE irrigation may also cause increases in soil salinity due to the salt concentration of the effluent (Table 1). In specific situations, high soil salinity can affect water uptake by plants due to the presence of higher $\mathrm{Na}^{+}, \mathrm{Cl}^{-}$and $\mathrm{HCO}_{3}^{-}$concentrations in the soil solution (Bielorai et al., 1984). Increases in soil salinity (measured by electrical conductivity) after TSE irrigation has been widely reported for agricultural (Latterell et al., 1982; Johns \& McConchie, 1994b; AlNakshabandi et al., 1997), pasture (Hortenstine, 1976) and forest systems (Smith et al., 1996b; Falkiner \& Smith, 1997; Speir et al., 1999). Moreover, increasing soil salinity was observed to be more pronounced in the topsoil (Cromer et al., 1984; Latterell et al., 1982; Al-Nakshabandi et al., 1997; Speir et al., 1999) due to superficial evaporation, leading to salt accumulation (Al-Nakshabandi et al., 1997).

Few studies were carried out related to the $S$, $\mathrm{B}$ and $\mathrm{Cl}$ dynamics in TSE irrigated soils. Quin \& Woods (1978) and Fonseca et al. (2005b) reported insignificant alterations in the availability of $S$ after TSE irrigation. With regard to $\mathrm{B}$, no changes were found in short term studies (Fonseca et al., 2005b). However, El-Nennah et al. (1982) verified long term increases in $\mathrm{B}$ availability. The $\mathrm{Cl}$ concentrations increased after TSE irrigation mainly in areas where the treatment process was accompanied by a chlorination step (Johns \& McConchie, 1994b; Falkiner \& Smith, 1997). 
Heavy metals have mostly low concentrations in domestic effluents (Bouwer \& Chaney, 1974; Feigin et al., 1991). However, the disposal of industrial effluents to the collecting and treatment system of domestic effluents can lead to increasing heavy metal concentrations in the TSE where they can be associated with: (i) the liquid fraction forming organo-metallic complexes capable to penetrate the soil with the irrigation water; and (ii) the suspended solid fraction, leading to accumulation in the surface soil (Feigin et al., 1991). In general, soils have high capacity to retain heavy metals due to: (i) low solubility and high specific adsorption, causing low concentrations in the soil solution; and (ii) presence of SOM affecting the solubility of heavy metals due to its capacity to form stable complexes with metal ions (organo-metallic complexes) leading to decreasing bioavailability (McBride, 1989; Stevenson, 1986).

Several studies on metal impacts on the soilplant system after TSE application revealed divergent outcomes such as decreases, increases or no alterations in bioavailable $\mathrm{Cd}, \mathrm{Cr}, \mathrm{Cu}, \mathrm{Fe}, \mathrm{Mn}, \mathrm{Ni}, \mathrm{Pb}$ and $\mathrm{Zn}$ concentrations. Mohammad \& Mazahreh (2003) observed no changes in the availability of $\mathrm{Cd}, \mathrm{Cr}, \mathrm{Cu}, \mathrm{Ni}, \mathrm{Pb}$ and Zn (extracted by DTPA-TEA ${ }^{\dagger}$ ) after TSE irrigation. Similar results were found by: Hayes et al. (1990a) for $\mathrm{Cu}$; Inglés et al. (1992) for $\mathrm{Cd}, \mathrm{Ni}$ and $\mathrm{Pb}$; Johns \& McConchie (1994b) for $\mathrm{Cu}, \mathrm{Cd}, \mathrm{Cr}$ and $\mathrm{Pb}$; Al-Jaloud et al. (1995) for Ni; Smith et al. (1996b) for $\mathrm{Cr}, \mathrm{Ni}, \mathrm{Pb}$ and $\mathrm{Zn}$; Ramirez-Fuentes et al. (2002) for $\mathrm{Cr}, \mathrm{Fe}$ and $\mathrm{Ni}$ (extracted with aqua regia); and Wang et al. (2003) for $\mathrm{Cd}, \mathrm{Cr}, \mathrm{Cu}, \mathrm{Ni}$ and $\mathrm{Zn}$ (extracted with aqua regia) in soils irrigated for more than 80 years with TSE. In other studies decreases in heavy metal availability were attributed to increasing $\mathrm{pH}$ after TSE irrigation (Falkiner \& Smith, 1997), including studies on Ni (Johns \& McConchie, 1994b), Cu, Mn, Zn (AlJaloud et al., 1995) and $\mathrm{Pb}$ (Paliwal et al., 1998). On the other hand, Quin \& Syers (1978) verified in pasture soils irrigated with TSE over 16 years slight increases in available $\mathrm{Cu}, \mathrm{Mn}$ and $\mathrm{Zn}$ concentrations (extracted with $0.1 \mathrm{~mol} \mathrm{~L}^{-1} \mathrm{HCl}$ solution). Also Siebe (1995) found slight increases in $\mathrm{Cd}, \mathrm{Cu}$ and $\mathrm{Zn}$ (extracted in aqua regia) in soils cropped with alfalfa and irrigated with TSE for more than 80 years. AlNakshabandi et al. (1997) observed higher concentrations of $\mathrm{Cd}, \mathrm{Cu}, \mathrm{Fe}, \mathrm{Mn}, \mathrm{Pb}$ and $\mathrm{Zn}$ in soil (extracted with DTPA-TEA) due to higher metal concentrations in the TSE. Nevertheless, due to the persistence of heavy metals in the environment the monitoring of these elements in soils under TSE irrigation over the long term is of crucial importance (Quin \& Syers, 1978; El-Nennah et al., 1982; Cameron et al., 1997; Bond, 1998; Yadav et al., 2002).

\section{CONCLUDING REMARKS AND SUGGESTIONS FOR FUTURE RESEARCH}

Due to the high $\mathrm{N}$ concentrations in TSE, nitrogen represents commonly the most important chemical component in the soil-plant system irrigated with effluents (Feigin et al., 1978). Therefore, the understanding of the transformation processes of effluent$\mathrm{N}$ in the soil and the $\mathrm{N}$ management are essential aspects for the sustainable use of TSE irrigation in agriculture (Bond, 1998). In this context, the uptake and accumulation of $\mathrm{N}$ in plants can be considered as one decisive factor to avoid undesirable $\mathrm{NO}_{3}^{-} \mathrm{N}$ leaching to the groundwater table (Bole \& Bell, 1978).

Sodium represents another important element within the soil-plant system after TSE application, especially when the effluent has a high sodium adsorption ratio (SAR) as e.g. at Lins, São Paulo State, Brazil (Fonseca et al., 2005a; Fonseca et al., 2007). After using these effluents for plant irrigation, Fonseca et al. $(2005 \mathrm{c})$ provided evidence of increasing $\mathrm{Na}$ concentrations in the soil and also in the plants (Fonseca et al., 2005b). Nevertheless, TSE rich in Na presents a high potential to be applied on perennial crops (Fonseca, 2005) such as forage plants (Bole \& Bell, 1978; Mohammad \& Ayadi, 2004), citrus (Zekri \& Koo, 1994; Reboll et al., 2000), forest plantations (Stewart et al., 1990) and forests under recuperation (Speir et al., 1999).

In most instances, where effluent irrigation was associated with decreases in yield and crop quality, the adverse effects can be attributed to a greater or lesser extent to one of the following factors:

a) The sewage treatment plant received wastewater amounts exceeding the treatment capacity associated with TSE of low quality;

b) High proportion of industrial wastewater input to the municipal sewage treatment plant resulting in higher concentrations of hazardous elements in the TSE and their transfer to the soil-water-plant system;

c) Lack of synchronization between TSE application rates and the water and/or nutrient requirements of the crops causing migration of mobile compounds (e.g. $\left.\mathrm{NO}_{3}^{-}-\mathrm{N}\right)$ to the subsoil;

d) Inadequate technical guidelines for monitoring of the soil-plant-effluent system.

DTPA-TEA: $0.005 \mathrm{~mol} \mathrm{~L}^{-1}$ diethylenetriaminepentaacetic acid $+0.1 \mathrm{~mol} \mathrm{~L}^{-1}$ triethanolamine $+0.01 \mathrm{~mol} \mathrm{~L}^{-1}$ calcium chloride, at $\mathrm{pH}$ 7.3 . 
On the other hand, the adequate nutrient supply to the plants by TSE can generally be associated to a greater or lesser extent to crop production systems with employment of low technology; crops cultivated on soils with high natural fertility or crop production systems with low nutrient requirements and elevated nutrient use efficiency such as forest plantations. However, several studies pointed out that the nutrient supply only by TSE irrigation can result in nutrient deficiency and decrease in yield (Maurer \& Davies, 1993; Overman et al., 1995; Fonseca et al., 2005a) which is expected to be more pronounced in tropical soils like those of Brazil with low natural fertility. In this context, it has to be highlighted that simple comparisons of wastewater components and mineral fertilizers cannot result in a clear-cut evaluation of the wastewater used, because the effects of the nutrients (principally $\mathrm{N}, \mathrm{P}$ and $\mathrm{K}$ ) in the wastewater are ambiguous. Therefore, factorial experiments are required, including additions of each of the nutrients separately and of various combinations of $\mathrm{N}, \mathrm{P}$ and $\mathrm{K}$ (Janssen et al., 2005).

The main changes in soils after agricultural TSE irrigation have been confined to the following parameters: TC, TN and mineral-N (in soil solution); microbial activity and composition of soil microbial communities and their function; exchangeable $\mathrm{Ca}$ and $\mathrm{Mg}$; salinity, sodicity, clay dispersion and hydraulic conductivity. For the other soil parameters considered in this review no significant changes and effects or agronomical-environmental implications were found over the short and medium terms.

With regard to plant nutrition and crop yield, future research in Brazil should focus on the TSE potential for $\mathrm{N}$ and $\mathrm{K}$ supply, especially for annual crops, perennial pastures (e.g. Cynodon, Chloris, Panicum and Pennisetum), forest plantations (mainly eucalyptus and pine) and energy crops. Orchards, despite being suitable for TSE irrigation, are subjected to restrictions in quality certification, according to the integrated crop management. In relation to this, the Euro-Retailer Produce Working Group - Good Agricultural Practice System (EUREP-GAP System), an European organization for the establishment of norms and standards for all steps in the production process of fruits and vegetables (including environmental, working, agricultural and commercial aspects) do not issue quality certificates for fruits cultivated under wastewater irrigation (Teixeira et al., 2003).

Regarding soil quality and $\mathrm{C}$ conditions after TSE irrigation, it is suggested that the evaluation of dissolved organic carbon (DOC) will become more essential because DOC is more sensitive to changes in the environment than soil organic carbon as a whole (Silveira, 2005). Also studies on the effects of SAR in
TSE on soil parameters such as Na contents, clay dispersion and hydraulic conductivity are of future interest especially for Brazilian soils. Moreover, further studies on effects of TSE irrigation on bioavailability of S, B and heavy metals are particularly required over the long term. Due to the importance of the microbial activity on the decomposition of organic residues, nutrient recycling, synthesis of humic substances and structural stability of soils, detailed investigations of microbial conditions and processes are crucial for a reliable evaluation of TSE irrigated soils. Future studies on TSE application should also focus on changes related to soil quality and the global involvement of ecosystem processes, including genetic diversity and characterization and changes in the structure of the edaphic community, microbial activity, biochemical activity, density of functional groups of microorganisms, sanitary quality and ecotoxicology (Oved et al., 2001; Ibekwe et al., 2003; Speir, 2002; Mantis et al., 2005). Additionally, further studies should not only monitor the concentrations of mineral- $\mathrm{N}$ in the soil solution but also estimate the losses of effluent- $\mathrm{N}$ by denitrification from TSE irrigated agro-systems especially in the context of global climate change.

Finally, the use of TSE in agriculture constitutes nowadays an important element in politics and management strategies of water resources. A critical decision making policy on TSE use may contribute to transform the negative image of sewage in the society to an economically and environmentally safe resource to preserve the existing water resources (Hespanhol, 2002). To achieve this target, further studies on the technical-economical viability as well as on environmental impacts of TSE disposal to diverse soil types and cropping systems under varying climatic conditions are required to establish reliable recommendations for the TSE use particularly on agro-systems in Brazil.

\section{ACKNOWLEDGEMENTS}

To FAPESP, CNPq and CAPES, for financial support, and to Sabesp for the logistic support.

\section{REFERENCES}

ACEA, M.J.; CARBALLAS, T. Microbial fluctuations after soil heating and organic amendment. Bioresource Technology, v.67, p.65-71, 1999.

AGENDA 21. Conferência das Nações Unidas sobre Meio Ambiente e Desenvolvimento, 1992, Rio de Janeiro. Brasília: Senado Federal, 1996. 585p.

AGUNWAMBA, J.C. Analysis of socioeconomic and environmental impacts of waste stabilization pond and unrestricted wastewater irrigation: interface with maintenance. Environmental Management, v.27, p.463-476, 2001. 
AL-JALOUD, A.A.; HUSSAIN, G.; AL-SAATI, A.J.; KARIMULLA, $S$. Effect of wastewater irrigation on mineral composition of corn and sorghum plants in a pot experiment. Journal of Plant Nutrition, v.18, p.1677-1692, 1995.

AL-JALOUD, A.A.; HUSSAIN, G.; KARIMULLA, S.; AL-HAMIDI, A.H. Effect of irrigation and nitrogen on yield and yield components of two rapeseed cultivars. Agricultural Water Management, v.30, p.57-68, 1996.

AL-NAKSHABANDI, G.A.; SAQQAR, M.M.; SHATANAWI, M.R.; FAYYAD, M.; AL-HORANI, H. Some environmental problems associated with the use of treated wastewater for irrigation in Jordan. Agricultural Water Management, v.34, p.81-94, 1997.

ARTIOLA, J.F.; PEPPER, I.L. Longterm influence of liquid sewage sludge on the organic carbon and nitrogen content of a furrowirrigated desert soil. Biology and Fertility of Soils, v.14, p.30-36, 1992.

ASANO, T., PETTYGROVE, G.S. Using reclaimed municipal wastewater for irrigation. California Agriculture, v.41 (3\&4), p.15$18,1987$.

ASANO, T.; MAEDA, M.; TAKAKI, M. Wastewater reclamation and reuse in Japan: overview and implementation examples. Water Science and Technology, v.34, p.219-226, 1996.

BALKS, M.R.; BOND, W.J.; SMITH, C.J. Effects of sodium accumulation on soil physical properties under an effluent-irrigated plantation. Australian Journal of Soil Research, v.36, p.821-830, 1998.

BANGE, M.P.; HAMMER, G.L.; RICKERT, K.G. Environmental control of potencial yield of sunflower in the subtropics. Australian Journal of Agricultural Research, v.48, p.231-240, 1997

BARTON, L.; SCHIPPER, L.A.; BARKLE, G.F.; McLEOD, M.; SPEIR, T.W.; TAYLOR, M.D.; McGILL, A.C.; VAN SCHAIK, A.P.; FITZGERALD, N.B.; PANDEY, S.P. Land application of domestic effluent onto four soil types: plant uptake and nutrient leachig. Journal of Environmental Quality, v.34, p.635-643, 2005.

BIELORAI, H.; VAISMAN, I.; FEIGIN, A. Drip irrigation of cotton with treated municipal effluents: I. Yield response. Journal of Environmental Quality, v.13, p.231-234, 1984.

BLUMENTHAL, U.J.; MARA, D.D.; PEASEY, A.; RUIZ-PALACIOS, G.; STOTT, R. Guidelines for the microbiological quality of treated wastewater used in agriculture: recommendations for revising WHO guidelines. Bulletin of the World Health Organization, v.78, p.1104-1116, 2000.

BOLAN, N.S; HEDLEY, M.J.; WHITE, R.E. Processes of soi acidification during nitrogen cycling with emphasis on legume based pastures. Plant and Soil, v.134, p.53-63, 1991.

BOLE, J.B.; BELL, R.G. Land application of municipal sewage waste water: yield and chemical composition of forage crops. Journal of Environmental Quality, v.7, p.222-226, 1978

BOND, W.J. Effluent irrigation - an environmental challenge for soil science. Australian Journal of Soil Research, v.36, p.543-555, 1998.

BOUWER, H. Integrated water management: emerging issues and challenges. Agricultural Water Management, v.45, p.217-228, 2000.

BOUWER, H.; CHANEY, R.L. Land treatment of wastewater. Advances in Agronomy, v.26, p.133-176, 1974.

BOUWER, H.; IDELOVITCH, E. Quality requirements for irrigation with sewage water. Journal of Irrigation and Drainage Engineering, v.113, p.516-535, 1987.

BRASIL. MINISTÉRIO DO PLANEJAMENTO, ORÇAMENTO E GESTÃO. Censo demográfico 2000: características da população e dos domicílios: resultados do universo. Rio de Janeiro: Instituto Brasileiro de Geografia e Estatística, 2001. 519p

CAMERON, K.C.; DI, H.J.; McLAREN, R.G. Is soil an appropriate dumping ground for our wastes? Australian Journal of Soil Research, v.35, p.995-1035, 1997

CROMER, R.N.; TOMPKINS, D.; BARR, N.J.; HOPMANS, P. Irrigation of Monterey pine with wastewater: effect on soil chemistry and groundwater composition. Journal of Environmental Quality, v.13, p.539-542, 1984.
DARWISH, M.R.; EL-AWAR, F.A.; SHARARA, M.; HAMDAR, B. Economic-environmental approach for optimum wastewater utilization in irrigation: a case study in Lebanon. Applied Engineering in Agriculture, v.15, p.41-48, 1999.

DAY, A.D.; TUCKER, T.C. Production of small grains pasture forage using sewage effluent as a source of irrigation water and plant nutrients. Agronomy Journal, v.51, p.569-572, 1959.

DAY, A.D.; TUCKER, T.C. Hay production of small grains utilizing city sewage effluent. Agronomy Journal, v.52, p.238-239, 1960.

DAY, A.D.; TUCKER, T.C. Effects of treated municipal waste water on growth, fiber, protein, and amino acid content of sorghum grain. Journal of Environmental Quality, v.6, p.325-327, 1977

DAY, A.D.; DICKSON, A.D.; TUCKER, T.C. Effects of city sewage effluent on grain yield and grain and malt quality of fall-sown, irrigated barley. Agronomy Journal, v.55, p.317-318, 1963.

DAY, A.D.; McFADYEN, J.A.; TUCKER,T.C.; CLUFF, C.B. Commercial production of wheat grain irrigated with municipal waste water and pump water. Journal of Environmental Quality, v.8, p.403-406, 1979.

DAY, A.D.; McFADYEN, J.A.; TUCKER,T.C.; CLUFF, C.B. Effects of municipal waste water on the yield and quality of cotton. Journal of Environmental Quality, v.10, p.47-49, 1981.

DAY, A.D.; RAHMAN, A., KATTERMAN, F.R.H.; JENSEN, V. Effects of treated municipal wastewater and commercial fertilizer on growth, fiber, acid-soluble nucleotides, protein, and amino acid content in wheat hay. Journal of Environmental Quality, v.3, p.17-19, 1974.

DAY, A.D. TAHER, F.A.; KATTERMAN, F.R.H. Influence of treated municipal waste water on growth, fiber, acid-soluble nucleotides, protein, and amino acid content in wheat grain. Journal of Environmental Quality, v.4, p.167-169, 1975.

DAY, A.D.; TUCKER, T.C.; VAVICH, M.G. Effect of city sewage effluent on the yield and quality of grain from barley, oats, and wheat. Agronomy Journal, v.54, p.133-135, 1962.

EL-NENNAH, M.; EL-KOBBIA, T.; SHEHATA, A.; EL-GAMAL, I. Effect of irrigation loamy sand soil by sewage effluents on its content of some nutrients and heavy metals. Plant and Soil, v.65, p.289-292, 1982.

FALKINER, R.A.; POLGLASE, P.J. Transport of phosphorus through soil in an effluent-irrigated tree plantation. Australian Journal of Soil Research, v.35, p.385-397, 1997.

FALKINER, R.A.; SMITH, C.J. Changes in soil chemistry in effluentirrigated Pinus radiata and Eucalyptus grandis. Australian Journal of Soil Research, v.35, p.131-147, 1997.

FEIGIN, A.; FEIGENBAUM, S.; LIMONI, H. Utilization efficiency of nitrogen from sewage effluent and fertilizer applied to corn plants growing in a clay soil. Journal of Environmental Quality, v.10, p.284-287, 1981.

FEIGIN, A.; RAVINA, I.; SHALHEVET, J. Irrigation with treated sewage effluent: management for environmental protection. Berlin: Springer-Verlag, 1991. 224p.

FEIGIN, A.; VAISMAN, I.; BIELORAI, H. Drip irrigation of cotton with treated municipal effluents: II. Nutrient availability in soil. Journal of Environmental Quality, v.13, p.234-238, 1984.

FEIGIN, A.; BIELORAI, H.; DAG, Y.; KIPNIS, T.; GISKIN, M. The nitrogen factor in the management of effluent-irrigated soils. Soil Science, v.125, p.248-254, 1978.

FITZPATRICK, G.; DONSELMAN, H.; CARTER, N.S. Interactive effects of sewage effluent irrigation and supplemental fertilization on container-grown trees. HortScience, v.21, p.92-93, 1986.

FLORES TENA, F.J.; MUÑOZ SALAS, E.M.; MORQUECHO BUENDÍA, O. Absorcion de cromo y plomo por alfalfa y pasto ovillo. Agrociencia, v.33, p.381-388, 1999.

FONSECA, A.F. Viabilidade agronômico-ambiental da disposição de efluente de esgoto tratado em um sistema solo-pastagem. Piracicaba, 2005. 174p. Tese (Doutorado) - Escola Superior de Agricultura Luiz de Queiroz, Universidade de São Paulo.

FONSECA, A.F., MELFI, A.J., MONTES, C.R. Maize growth and changes in soil fertility after irrigation with treated sewage effluent. I. Plant dry matter yield and soil nitrogen and phosphorus availability. Communications in Soil Science and Plant Analysis, v.36, p.1965$1981,2005 \mathrm{a}$ 
FONSECA, A.F., MELFI, A.J., MONTES, C.R. Maize growth and changes in soil fertility after irrigation with treated sewage effluent. II. Soil acidity, exchangeable cations, and sulfur, boron and heavy metals availability. Communications in Soil Science and Plant Analysis, v.36, p.1983-2003, 2005b.

FONSECA, A.F., ALLEONI, L.R.F.; MELFI, A.J., MONTES, C.R. Cation exchange capacity of an Oxisol amended with an effluent from domestic sewage treatment. Scientia Agricola, v.62, p.552$558,2005 \mathrm{c}$.

FONSECA, A.F.; MELFI, A.J.; MONTEIRO, F.A.; MONTES, C.R.; ALMEIDA, V.V.; HERPIN, U. Treated sewage effluent as a source of water and nitrogen for Tifton 85 bermudagrass. Agricultural Water Management, v.87, p.328-336, 2007.

FRIEDEL, J.K.; LANGER, T.; SIEBE, C.; STAHR, K. Effects of longterm waste water irrigation on soil organic matter, soil microbial biomass and its activities in central Mexico. Biology and Fertility of Soils, v.31, p.414-421, 2000.

GADALLAH, M.A.A. Effects of industrial and sewage waste water on the concentration of soluble carbon, nitrogen, and some mineral elements in sunflower plants. Journal of Plant Nutrition, v.17, p.1369-1384, 1994.

GONÇALVES, J.L.M.; STAPE, J.L.; BENEDETTI, V.; FESSEL, V.A.G.; GAVA, J.L. Reflexos do cultivo mínimo e intensivo do solo em sua fertilidade e na nutrição das árvores. In: GONÇALVES, J.L.M.; BENEDETTI, V. (Ed.) Nutrição e fertilização florestal. Piracicaba: Instituto de Pesquisa e Estudos Florestais, 2000. p.1-57.

GRATTAN, S.R.; GRIEVE, C.M.; POSS, J.A.; ROBINSON, P.H.; SUAREZ, D.L.; BENES, S.E. Evaluation of salt-tolerant forages for sequential water reuse systems. I. Biomass production. Agricultural Water Management, v.70, p.109-120, 2004.

GRIEVE, C.M.; POSS, J.A.; GRATTAN, S.R.; SUAREZ, D.L.; BENES, S.E.; ROBINSON, P.H. Evaluation of salt-tolerant forages for sequential water reuse systems. II. Plant-ion relations. Agricultural Water Management, v.70, p.121-135, 2004.

HALL, S.J.; MATSON, P.A. Nitrogen oxide emissions after additions in tropical forests. Nature, v.400, p.152-155, 1999.

HALLIWELL, D.J.; BARLOW, K.M.; NASH, D.M. A review of the effects of wastewater sodium on soil physical properties and their implications for irrigation systems. Australian Journal of Soil Research, v.39, p.1259-1267, 2001.

HAYES, A.R.; MANCINO, C.F.; PEPPER, I.L. Irrigation of turfgrass with secondary sewage effluent. I. Soil and leachate water quality. Agronomy Journal, v.82, p.939-943, 1990a.

HAYES, A.R.; MANCINO, C.F.; FORDEN, W.Y.; KOPEC, D.M.; PEPPER, I.L. Irrigation of turfgrass with secondary sewage effluent. II. Turf quality. Agronomy Journal, v.82, p.943-946, 1990b.

HESPANHOL, I. Potencial de reuso de água no Brasil - agricultura, indústria, municípios e recarga de aqüíferos. Revista Brasileira de Recursos Hídricos, v.7, p.75-95, 2002.

HOOK, J.E. Movement of phosphorus and nitrogen in soil following application of municipal wastewater. In: NELSON, D.W.; ELRICK, D.E.; TANJI, K.K. (Ed.) Chemical mobility and reactivity in soil systems. Madison: Soil Science Society of America, 1981. p.241255 .

HOOK, J.E.; KARDOS, L.T. Nitrate leaching during long-term spray irrigation for treatment of secondary sewage effluent on woodland sites. Journal of Environmental Quality, v.7, p.30-34, 1978.

HORTENSTINE, C.C. Chemical changes in the soil solution from a Spodosol irrigated with secondary-treated sewage effluent. Journal of Environmental Quality, v.5, p.335-338, 1976.

HUSSAIN, G.; AL-JALOUD, A.A. Effect of irrigation and nitrogen on yield, yield components and water use efficiency of barley in Saudi Arabia. Agricultural Water Management, v.36, p.55-70, 1998.

HUSSAIN, G.; AL-JALOUD, A.A.; KARIMULLA, S. Effect of treated effluent irrigation and nitrogen on yield and nitrogen use efficiency of wheat. Agricultural Water Management, v.30, p.175-184, 1996.

IBEKWE, A.M.; GRIEVE, C.M.; LYON, S.R. Characterization of microbial communities and composition in constructed dairy wetland wastewater effluent. Applied and Environmental Microbiology, v.69, p.5060-5069, 2003.
INGLÉS, A.; GÓMEZ, M.; NOGALES, R. Efecto del riego con aguas residuales urbanas depuradas sobre la disponibilidad de metales pesados para la planta. Suelo y Planta, v.2, p.703-712, 1992.

JANSSEN, B.H.; BOESVELD, H.; JUSTO RODRIGUEZ, M. Some theoretical considerations on evaluating wastewater as a source of $\mathrm{N}$, P, and K for crops. Irrigation and Drainage, v.54, p.S35-S47, 2005.

JEYARAMAN, S. Influence of N levels of crude protein yield of hybrid napier under sewage effluent irrigation. Indian Journal of Agronomy, v.33, p.326-327, 1988.

JOHNS, G.G.; McCONCHIE, D.M. Irrigation of bananas with secondary treated sewage effluent. I. Field evaluation of effect on plant nutrients and additional elements in leaf, pulp and soil. Australian Journal of Agricultural Research, v.45, p.1601-1617, 1994a.

JOHNS, G.G.; McCONCHIE, D.M. Irrigation of bananas with secondary treated sewage effluent. II. Effect on plant nutrients, additional elements and pesticide residues in plants, soil and leachate using drainage lysimeters. Australian Journal of Agricultural Research, v.45, p.1619-1638, 1994b.

JORDAN, M.J.; NADELHOFFER, K.J.; FRY, B. Nitrogen cycling in forest and grass ecosystems irrigated with ${ }^{15} \mathrm{~N}$-enriched wastewater. Ecological Applications, v.7, p.864-881, 1997.

KARDOS, L.T.; HOOK, J.E. Phosphorus balance in sewage effluent treated soils. Journal of Environmental Quality, v.5, p.87-90, 1976.

KARLEN, D.L.; VITOSH, M.L.; KUNZE, R.J. Irrigation of corn with simulated municipal sewage effluent. Journal of Environmental Quality, v.5, p.269-273, 1976.

KERN, J.; IDLER, C. Treatment of domestic and agricultural wastewater by reed bed systems. Ecological Engineering, v.12, p.13-25, 1999.

KUZYAKOV, Y.; FRIEDEL, J.K.; STAHR, K. Review of mechanisms and quantification of priming effects. Soil Biology \& Biochemistry, v.32, p.1485-1498, 2000.

LATTERELL, J.J.; DOWDY, R.H.; CLAPP, C.E.; LARSON, W.E.; LINDEN, D.R. Distribution of phosphorus in soils irrigated with municipal waste-water effluent: a 5-year study. Journal of Environmental Quality, v.11, p.124-128, 1982.

LÉON SUEMATSU, G.; MOSCOSO CAVALLINI, J. Tratamento e uso de águas residuárias. Campina Grande: Universidade Federal da Paraíba, 1999. 109p.

LINDEN, D.R.; CLAPP, C.E.; GILLEY, J.R. Effects of scheduling municipal waste-water effluent irrigation of reed canarygrass on nitrogen renovation and grass production. Journal of Environmental Quality, v.10, p.507-510, 1981.

LUND, L.J.; PAGE, A.L.; NELSON, C.O.; ELLIOTT, R.A. Nitrogen balances for an effluent irrigation area. Journal of Environmental Quality, v.10, p.349-352, 1981.

LURIE, S.; ZILKAH, S.; DAVID, I.; LAPSKER, Z.; ARIE, R.B. Quality of "Flamekist" nectarine fruits from on orchard irrigated with reclaimed sewage water. Journal of Horticultural Science, v.71, p.313-319, 1996.

MANCINO, C.F.; PEPPER, I.L. Irrigation of turfgrass with secondary sewage effluent: soil quality. Agronomy Journal, v.84, p.650-654, 1992.

MAGESAN, G.N.; McLAY, C.D.A.; LAL, V.V. Nitrate leaching from a free-draining volcanic soil irrigated with municipal sewage effluent in New Zealand. Agriculture, Ecosystems and Environment, v.70, p.181-187, 1998.

MANTIS, I.; VOUTSA, D.; SAMARA, C. Assessment of the environmental hazard from municipal and industrial wastewater treatment sludge by employing chemical and biological methods. Ecotoxicology and Environmental Safety, v.62, p.397-407, 2005.

MARSCHNER, H. Mineral nutrition of higher plants. 2.ed. London: Academic Press, 1995. 889p.

MAURER, M.A.; DAVIES, F.S. Microsprinkler irrigation of young "Redblush" grapefruit trees using reclaimed water. HortScience, v.28, p.1157-1161, 1993.

MEDEIROS, S.S.; SOARES, A.A.; FERREIRA, P.A.; NEVES, J.C.L.; MATOS, A.T.; SOUZA, J.A.A. Utilização de água residuária de origem doméstica na agricultura: estudo das alterações químicas do solo. Revista Brasileira de Engenharia Agrícola e Ambiental, v.9, p.603-612, 2005. 
MEKKI, A.; DHOUIB, A.; SAYADI, S. Changes in microbial and soil properties following amendment with treated and untreated olive mill wastewater. Microbiological Research, v.161, p.93-101, 2006.

McBRIDE, M.B. Reactions controlling heavy metal solubility in soils. Advances in Soil Science, v.10, p.1-57, 1989.

McLAIN, J.E.T.; MARTENS, D.A. $\mathrm{N}_{2} \mathrm{O}$ production by heterotrophic $\mathrm{N}$ transformations in a semiarid soil. Applied Soil Ecology, v.32, p.253263, 2006

MOHAMMAD, M.J.; AYADI, M. Forage yield and nutrient uptake as influenced by secondary treated wastewater. Journal of Plant Nutrition, v.27, p.351-364, 2004.

MOHAMMAD, M.J.; MAZAHREH, N. Changes in soil fertility parameters in response to irrigation of forage crops with secondary treated wastewater. Communications in Soil Science and Plant Analysis, v.34, 1281-1294, 2003.

MUJERIEGO, R.; SALA, L.; CARBÓ, M.; TURET, J. Agronomic and public health assessment of reclaimed water quality for landscape irrigation. Water Science and Technology, v.33, p.335-344, 1996.

MYERS, R.J.K.; CAMPBELL, C.A.; WEIER, K.L. Quantitative relationship between net nitrogen mineralization and moisture content of soils. Canadian Journal of Soil Science, v.62, p.111-124, 1982.

NURK, K.; TRUU, J.; TRUU, M.; MANDER, Ü. Microbial characteristics and nitrogen transformation in planted soil filter for domestic wastewater treatment. Journal of Environmental Science and Health Part A - Toxic/Hazardous Substances \& Environmental Engineering, v.40, p.1201-1214, 2005.

ORON, G.; CAMPOS, C.; GILLERMAN, L.; SALGOT, M. Wastewater treatment, renovation and reuse for agricultural irrigation in small communities. Agricultural Water Management, v.38, p.223-234, 1999.

OVERMAN, A.R. Irrigation of corn with municipal effluent. Transactions of the American Society of Agricultural Engineers, v.24, p.74-80, 1981

OVERMAN, A.R.; NGUY, A. Growth response and nutrient uptake by forage crops under effluent irrigation. Communication in Soil Science and Plant Analysis, v.6, p.81-93, 1975.

OVERMAN, A.R.; WILSON, D.M.; VIDAK, W.; ALLHANDS, M.N.; PERRY JR., T.C. Model for partitioning of dry matter and nutrients in corn. Journal of Plant Nutrition, v.18, p.959-968, 1995.

OVED, T.; SHAVIV, A.; GOLDRATH, T.; MANDELBAUM, R.T.; MINZ, D. Influence of effluent irrigation on community composition and function of ammonia-oxidizing bacteria in soil. Applied and Environmental Microbiology, v.67, p.3426-3433, 2001.

PALIWAL, K. KARUNAICHAMY, K.S.T.K.; ANANTHAVALLI, M. Effect of sewage water irrigation on growth performance, biomass and nutrient accumulation in Hardwickia binata under nursery conditions. Bioresource Technology, v.66, p.105-111, 1998.

PESCOD, M.B. Wastewater treatment and use in agriculture. Rome: Food and Agriculture Organization, 1992. 125p. (Irrigation and Drainage Paper, 47).

POLGLASE, P.J.; TOMPKINS, D.; STEWART, L.G.; FALKINER, R.A Mineralization and leaching of nitrogen in an effluent-irrigated pine plantation. Journal of Environmental Quality, v.24, p.911-920, 1995.

POLLICE, A.; LOPEZ, A.; LAERA, G.; RUBINO, P.; LONIGRO, A. Tertiary filtered municipal wastewater as alternative water source in agriculture: a field investigation in Southern Italy. Science of the Total Environment, v.324, p.201-210, 2004.

QUIN, B.F. Irrigation with sewage effluent. New Zealand Journal of Agriculture, v.5, p.30-32, 1978.

QUIN, B.F.; FORSYTHE, L.J. Surface irrigation of pasture with treated sewage effluent. II. Drainage losses of nitrate and other nutrients. New Zealand Journal of Agricultural Research, v.21, p.427-434, 1978.

QUIN, B.F.; SYERS, J.K. Surface irrigation of pasture with treated sewage effluent. III. Heavy metal content of sewage effluent, sludge, soil, and pasture. New Zealand Journal of Agricultural Research, v.21, p.435-442, 1978.

QUIN, B.F.; WOODS, P.H. Surface irrigation of pasture with treated sewage effluent. I. Nutrient status of soil and pastures. New Zealand Journal of Agricultural Research, v.21, p.419-426, 1978.
QUIRK, J.P.; SCHOFIELD, R.K. The effect of electrolyte concentration on soil permeability. Journal of Soil Science, v.6, p.163-178, 1955.

RAMIREZ-FUENTES, E.; LUCHO-CONSTANTINO, C; ESCAMILLA-SILVA, E.; DENDOOVEN, L. Characteristics, and carbon and nitrogen dynamics in soil irrigated with wastewater for different lengths of time. Bioresource Technology, v.85, 179-187, 2002.

RAYDEN, J.C.; PRATT, P.F. Phosphorus removal from wastewater applied to land. Hilgardia, v.48, p.1-36, 1980.

REBOLL, V.; CEREZO, M.; ROIG, A.; FLORS, V.; LAPEÑA, L.; GARCÍA-AGUSTÍN, P. Influence of wastewater vs groundwater on young Citrus trees. Journal of the Science of Food and Agriculture, v.80, p.1441-1446, 2000.

SANTAMARÍA, J.; TORANZOS, G.A. Enteric pathogens and soil: a short review. International Microbiology, v.6, p.5-9, 2003.

SCHIPPER, L.A.; WILLIAMSON, J.C.; KETTLES, H.A; SPEIR, T.W. Impact of land-applied tertiary-treated effluent on soil biochemical properties. Journal of Environmental Quality, v.25, p.1073-1077, 1996.

SEGARRA, E.; DARWISH, M.R.; ETHRIDGE, D.E. Returns to municipalities from integrating crop production with wastewater disposal. Resources, Conservation and Recycling, v.17, p.97-107, 1996.

SHAHALAM, A.; ZAHRA, B.M.A.; JARADAT, A. Wastewater irrigation effect on soil, crop and environment: a pilot scale study at Irbid, Jordan. Water, Air, and Soil Pollution, v.106, p.425-445, 1998.

SIEBE, C. Heavy metal availability to plants in soils irrigated with wastewater from Mexico City. Water Science and Technology, v.32, p.29-34, 1995

SILVEIRA, M.L.A. Dissolved organic carbon and bioavailability of N and $\mathrm{P}$ as indicators of soil quality. Scientia Agricola, v.62, p.502508,2005

SMITH, C.J.; BOND, W.J. Losses of nitrogen from an effluent-irrigated plantation. Australian Journal of Soil Research, v.37, p.371-389, 1999.

SMITH, C.J.; FRENEY, J.R.; BOND, W.J. Ammonia volatilization from soil irrigated with urban sewage effluent. Australian Journal of Soil Research, v.34, p.789-802, 1996a.

SMITH, C.J.; HOPMANS, P.; COOK, F.J. Accumulation of $\mathrm{Cr}, \mathrm{Pb}, \mathrm{Cu}$, $\mathrm{Ni}, \mathrm{Zn}$ and $\mathrm{Cd}$ in soil following irrigation with treated urban effluent in Australia. Environmental Pollution, v.94, p.317-323, 1996b.

SMITH, G.S.; MIDDLETON, K.R.; EDMONDS, A.S. Classification of pasture and fodder plants according to their ability to translocate sodium from their roots into aerial parts. New Zealand Journal of Experimental Agriculture, v.6, p.183, 1978.

SMITH, J.H.; PETERSON, J.R. Recycling of nitrogen through land application of agricultural, food processing, and municipal wastes. In: STEVENSON, F.J. (Ed.). Nitrogen in agricultural soils. 2.ed. Madison: American Society of Agronomy/Soil Science Society of America, 1982. p.791-831.

SNOW, V.O.; SMITH, C.J.; POLGLASE, P.J.; PROBERT, M.E. Nitrogen dynamics in a eucalypt plantation irrigated with sewage effluent or bore water. Australian Journal of Soil Research, v.37, p.527-544, 1999.

SOMMERS, L.E.; NELSON, D.W.; OWENS, L.B. Status of inorganic phophorus in soils irrigated with municipal wastewater. Soil Science, v.127, p.340-350, 1979.

SPEIR, T.W. Soil biochemical properties as indices of performance and sustainability of effluent irrigation systems in New Zealand: a review. Journal of The Royal Society of New Zealand, v.32, p.535-553, 2002.

SPEIR, T.W.; VAN SCHAIK, A.P.; KETTLES, H.A.; VICENT, K.W.; CAMPBELL, D.J. Soil and stream-water impacts of sewage effluent irrigation onto steeply sloping land. Journal of Environmental Quality, v.28, p.1105-1114, 1999.

STEVENSON, F.J. Cycles of soil: carbon, nitrogen, phosphorus, sulfur, micronutrients. New York: John Wiley, 1986. 380p.

STANFORD, G.; SMITH, S.J. Nitrogen mineralization potentials of soils. Soil Science Society of America Proceedings, v.36, p.465-472, 1972. 
STEWART, H.T.L.; HOPMANS, P.; FLINN, D.W. Nutrient accumulation in trees and soil following irrigation with municipal effluent in Australia. Environmental Pollution, v.63, p.155-177, 1990.

SU, J.J.; YEH, K.S.; TSENG, P.W. A strain of Pseudomonas sp. isolated from piggery wastewater treatment systems with heterotrophic nitrification capability in Taiwan. Current Microbiology, v.53, p.7781, 2006.

TANJI, K.K. Irrigation with marginal quality waters: issues. Journal of Irrigation and Drainage Engineering, v.123, p.165-169, 1997.

TEIXEIRA, M.M.; RODRIGUES, G.J.; CUNHA, J.P.A.R. Rastreabilidade: uma nova meta para a fruticultura nacional. In: ZAMBOLIM, L. (Ed.). Manejo Integrado: produção integrada de fruteiras tropicais - doenças e pragas. Viçosa: Departamento de Fitopatologia - Universidade Federal de Viçosa, 2003. p.457-516.

TOZE, S. Reuse of effluent water - benefits and risks. Agricultural Water Management, v.80, p.147-159, 2006.

UNITED STATES ENVIRONMENTAL PROTECTION AGENCY

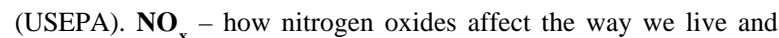
breathe. Research Triangle Park: USEPA/Office of Air Quality Planning \& Standards, 1998. 6p.

VAZQUEZ-MONTIEL, O.; HORAN, N.J.; MARA, D.D. Management of domestic wastewater for reuse in irrigation. Water Science and Technology, v.33, p.355-362, 1996.

VON SPERLING, M. Introdução à qualidade das águas e ao tratamento de esgoto. Belo Horizonte: Departamento de Engenharia Sanitária e Ambiental - Universidade Federal de Minas Gerais, 1995. 243p.
VON SPERLING, M. Lagoas de estabilização. Belo Horizonte: Departamento de Engenharia Sanitária e Ambiental - Universidade Federal de Minas Gerais, 1996. 134p.

WANG, Z.; CHANG, A.C.; WU, L.; CROWLEY, D. Assessing the soil quality of long-term reclaimed wastewater-irrigated cropland. Geoderma, v.114, p.261-278, 2003.

WESTCOT, D.W. Quality control of wastewater for irrigated crop production. Rome: Food and Agriculture Organization, 1997. 97p. (Water Reports, 10).

YADAV, R.K.; GOYAL, B.; SHARMA, R.K.; DUBEY, S.K.; MINHAS, P.S. Post-irrigation impact of domestic sewage effluent on composition of soils, crops and ground water. A case study. Environment International, v.28, p.481-486, 2002.

YAN, F.; SCHUBERT, S.; MENGEL, K. Soil pH increase due to biological descarboxilation of organic anions. Soil Biology \& Biochemistry, v.28, p.617-624, 1996.

ZEKRI, M.; KOO, R.C.J. Treated municipal wastewater for citrus irrigation. Journal of Plant Nutrition, v.17, p.693-708, 1994.

Received January 02, 2007

Accepted January 25, 2007 